\title{
Effect of cassava peel meal on morphometric characteristics of reproductive organs and visceral organ weights of Cockerels
}

\author{
Christian O. Ezihe \\ Department of Veterinary Physiology, Pharmacology and Biochemistry, University of Agriculture, Makurdi, Nigeria. \\ Email: chrisezihe@yahoo.com. Tel: +2348034439824. \\ Copyright (@) 2017 Ezihe. This article remains permanently open access under the terms of the Creative Commons Attribution License 4.0, which \\ permits unrestricted use, distribution, and reproduction in any medium, provided the original work is properly cited.
}

Received 20th April, 2017; Accepted 10th May, 2017

\begin{abstract}
This study was designed to evaluate the effect of cassava peel meal on the morphometric characteristics of reproductive organs and visceral organ weights of cockerels. Four treatment diets were formulated to contain $0 \%(1)$, $10 \%$ (2), 20\% (3) and 30\% (4) cassava peel meals (CPM) respectively. Forty cockerels, 24 weeks of age, were randomly assigned to the four treatment diets with two replicates of five birds per treatment group. Data were collected on morphometric characteristics of the reproductive organs as well as the visceral organ weights. Data were subjected to analysis of variance (ANOVA) and significant means were separated using Duncan's multiple range test. The results of this study showed non-significant differences $(P>0.05)$ in right and left testicular weights, paired testicular weights, right and left epididymal weights, paired epididymal weights, right and left ductus deferens, and paired ductus deferens. There were also non-significant differences $(P>0.05)$ in the average heart weights, gizzard weights, abdominal fat weight and percentage, average spleen weights, liver weights, lungs and kidney weights. It could be concluded from this study that dietary inclusion of sun-dried cassava peel meal up to a level of $30 \%$ has no adverse effect on the morphometric characteristics of the reproductive organs as well as the visceral organ weights of cockerels.
\end{abstract}

Key words: Analysis, Bovans, diets, poultry, processed.

\section{INTRODUCTION}

Africa is currently plagued with a food crisis, partly due to the unprecedented rise in human population and the alarming drop in per capita food production particularly in the last decade. Low intake of protein has repercussions and adverse effects on the economy of a country not only in terms of pronounced malnutrition and in terms of diseases resulting in reduced human productivity, but also in the incidence of infant mortality. In Nigeria, limited supplies of protein and energy carriers (soya beans, groundnut cake fishmeal, maize, etc.) and consequent importation usually results in significant increases in the cost of domestic livestock production (Cantner, 1987). The shortage of protein in Nigeria and the rapidly increasing demand of livestock products could be alleviated through the production of poultry meat and eggs.

Livestock production plays a very important role in the national economy and its estimated contribution to the national Gross Domestic Products (GDP) is placed at between 5 to $6 \%$, which accounts for nearly 15 to $20 \%$ of the agricultural GDP (Ahmed, 2004). The poultry industry has a great potential in realizing the poultry demand of the country due to its fast growth rate, high creation of employment opportunities, high turnover rate of animal protein as well as provision of high quality meat and eggs for human consumption.

Feed makes up at least $60 \%$ of the cost of production for all animal species and sometimes as much as $85 \%$ (Gill, 2003). It holds a vital position in bridging the animal supply and demand gap in developing countries like Nigeria. Conventional feed ingredients such as maize have become insufficient for livestock feeding due to increasing demand for human consumption as well as livestock feeding. In order to reduce the cost of poultry 
production, the nutritional potential of unconventional feed sources mainly energy and protein, which are cheap and locally available need to be investigated. One of such feed sources is cassava (Manihot spp), which forms the main starchy food for many people living in Sub-Saharan Africa (Parr et al., 1988). Cassava peels are the main byproducts of cassava-based industries and are available in large quantities in the country. Since cassava peels are not directly consumed by humans, they can serve as alternative or non-conventional feed ingredient for livestock and poultry. Many reports (Osei and Duodu, 1988; Ogbonna, 1991; Ogbonna and Adebowale, 1993) have shown that cassava peels can replace maize in poultry rations without marked adverse effects on the performance of birds. Incorporation of processed cassava peels into cockerel ration reduced the cost of production without adverse effect on the carcass quality and economy of feed conversion of birds (Aina, 1990). Dairo and Egbeyemi (2012) reported that mixture of cassava peel and caged layer manure can be included in weaner rabbit diets up to $25 \%$ without adverse effect on their growth performance. Adeyemo et al. (2013) reported that maize can be replaced with up to $50 \%$ hydrolyzed cassava peels in chicken feed without deleterious effects. Oladunjoye et al. (2014) reported that $15 \%$ cassava peel meal can be included in broiler chicken diets using $0.2 \%$ methionine but the use of $20 \%$ CPM requires supplementation with $0.4 \%$ methionine. Cassava peel meal can be made a better feed stuff by improving the digestibility of the high fibre component and degrade its anti-nutritional factor by supplementing with enzyme (Midau et al., 2011). Abu et al. (2015) reported that 20\% inclusion of cassava leaf meal and $20 \%$ cassava peel meal as replacement for soya bean meal and maize respectively could be used in both broiler starter and finisher diets without any deleterious effect on growth and carcass yield of broiler chickens. There is need to investigate the effect of cassava peel meal on reproductive parameters of chickens. Therefore, this research was conducted to evaluate the effect of cassava peel meal on the morphometric characteristics of reproductive organs and visceral organ weights of cockerels.

\section{MATERIALS AND METHODS}

\section{Experimental location}

The experiment was conducted at the Poultry Unit, Livestock Teaching and Research Farm, University Of Agriculture, Makurdi, Benue state, Nigeria. Benue State is a state in the mid-belt region of Nigeria with a population of about 4,253,641 in 2006 census. Its geographic coordinates are Longitude $7^{\circ} 47^{\prime}$ and $10^{\circ} 0^{\prime}$ East and Latitude $6^{\circ} 25^{\prime}$ and $8^{\circ} 8^{\prime}$ North. The annual rainfall ranges from 100 to $200 \mathrm{~mm}$ and Temperature fluctuates between 21 to $37^{\circ} \mathrm{C}$ (https://en.wikipedia.org/ wiki/Benue_State).

\section{Formulation of experimental diets}

Fresh cassava peels were collected from Garri processing centers in North Bank area of Makurdi in Benue State, Nigeria. The cassava peels were thoroughly washed to remove sand particles and subsequently sundried for a period of 5 to 7 days and hammer milled for use. Four experimental diets were formulated to contain $0 \%(1), 10 \%(2), 20 \%$ (3) and $30 \%$ (4) cassava peel meal respectively (Table 1$)$.

\section{Experimental birds and management}

Forty, twenty-four weeks old, Bovans cockerels of between 1.83 to $2.07 \mathrm{~kg}$ were used for this study. The birds were hatched at The Evangelical Church of West Africa (ECWA) rural Development Farm, Jos, in the Middle Belt of Nigeria. The birds were given water and corresponding diets ad-libitum for eight weeks.

\section{Experimental design and data collection}

The birds were randomly assigned to four treatment diets. The birds in each treatment group were further divided into two replicates of five birds each in a completely randomized design (CRD). The reproductive organs were dissected free of fats and adhering tissues before evaluation of their weights. The visceral and reproductive organs weights were measured using a digital balance. Relative values of the visceral and reproductive organs were determined by dividing the organ weights by the live weights of the respective cockerels.

\section{Statistical analysis}

Data collected from this study were subjected to analysis of variance (ANOVA) and the means where significant, were separated using Duncan's Multiple Range Test (Steel and Torrie, 1980).

\section{RESULTS AND DISCUSSION}

The effects of cassava peel meal on morphometric characteristics of reproductive organs of cockerels are shown in Table 2 while the effects of cassava peel meal on the visceral organ weights of cockerels are presented in Table 3. There were non-significant differences $(P>0.05)$ in right and left testicular weights, paired testicular weights, right and left epididymal weights, paired epididymal weights, right and left ductus deferens, and paired ductus deferens of cockerels in the different dietary groups. There were also non-significant differences $(P>0.05)$ in the average heart weights, gizzard weights, abdominal fat weight and percentage, average spleen weights, liver weights, lungs and kidney 
Table 1. Percentage Composition of Diets.

\begin{tabular}{lcccc}
\hline \multirow{2}{*}{ Feedstuff } & \multicolumn{3}{c}{ Diets } \\
\cline { 2 - 5 } & $\mathbf{1 ~ ( 0 \% )}$ & $\mathbf{2 ~ ( 1 0 \% )}$ & $\mathbf{3 ~ ( 2 0 \% )}$ & $\mathbf{4}(\mathbf{3 0} \%)$ \\
\hline Cassava Peel Meal & 0 & 10.00 & 20.00 & 30.00 \\
Groundnut Cake & 25.00 & 25.00 & 25.00 & 25.50 \\
Maize & 55.00 & 50.00 & 46.00 & 39.41 \\
Rice Offal & 16.23 & 11.15 & 5.01 & - \\
Palm Oil & - & - & - & 1.00 \\
Bone Meal & 3.00 & 3.00 & 3.10 & 3.18 \\
Premix (Grower) & 0.25 & 0.25 & 0.25 & 0.25 \\
Lysine & 0.10 & 0.15 & 0.16 & 0.17 \\
Methionine & 0.17 & 0.20 & 0.23 & 0.24 \\
Salt & 0.25 & 0.25 & 0.25 & 0.25 \\
Total & 100.00 & 100.00 & 100.00 & 100.00 \\
Calculated Analysis & & & & \\
Crude Protein \% & & & 16.84 & 16.74 \\
Energy (Kcal/ kg ME) & 17.00 & 17.00 & 2656 & 2657 \\
Calcium \% & 2707 & 2674 & 1.11 & 1.18 \\
Total Phosphorus \% & 1.08 & 1.08 & 0.80 & 0.81 \\
Available Phosphorus \% & 0.80 & 0.79 & 0.62 & 0.63 \\
Methionine + Cystine \% & 0.60 & 0.60 & 0.61 & 0.60 \\
Lysine \% & 0.60 & 0.60 & 0.70 & 0.70 \\
Crude Fat \% & 0.70 & 0.70 & 3.43 & 3.34 \\
Crude Fiber\% & 3.70 & 3.60 & 8.25 & 8.36 \\
Hydrogen Cyanide(g/kg) & 8.54 & 8.44 & 2.00 & 3.00 \\
\hline
\end{tabular}

Pfizer Grower Premix at the rate of inclusion provides the following additional nutrients per kg of diet: Vitamin A 3.200 i.u, Vitamin D 3.640 i.u, Vitamin E 2 i.u., Vitamin K 0.8 mgr, Thiamine, $B_{1} 0.6$ mgr, Riboflavin, $B_{2} 1.6$ mgr, Pyridoxine, $B_{6} 0.6$ mgr, Niacin 6 mgr, vitamin $B_{12}$ $0.004 \mathrm{mgr}$, Panthothenic Acid $2 \mathrm{mgr}$, Folic Acid $0.2 \mathrm{mgr}$, biotin $0.008 \mathrm{mgr}$, Choline Chloride $0.08 \mathrm{gr}$, Antioxidant $0.05 \mathrm{gr}$, manganese $0.032 \mathrm{gr}$, Zinc 0.02gr, Iron, 0.008gr, Copper 0.002gr, lodine 0.00048gr, Selenium 0.08mgr and Cobalt 0.08mgr.

Table 2. Effect of Cassava peel meal on the morphometric characteristics of reproductive organs of Cockerels (Mean \pm SEM).

\begin{tabular}{lccccc}
\hline \multirow{2}{*}{ Parameter } & \multicolumn{3}{c}{ Diets } & \multirow{2}{*}{ LS } \\
\cline { 2 - 5 } & $\mathbf{1 ( 0 \% )}$ & $\mathbf{2 ( 1 0 \% )}$ & $\mathbf{3 ( 2 0 \% )}$ & $\mathbf{4 ( 3 0 \% )}$ & \\
\hline Left Testicular Weight $(\mathrm{g})$ & $11.35 \pm 1.09$ & $11.97 \pm 1.41$ & $13.03 \pm 1.17$ & $10.62 \pm 0.09$ & $\mathrm{~ns}$ \\
Right Testicular Weight $(\mathrm{g})$ & $10.92 \pm 1.01$ & $11.80 \pm 1.24$ & $12.73 \pm 1.37$ & $10.73 \pm 1.21$ & $\mathrm{~ns}$ \\
Paired Testicular Weight $(\mathrm{g})$ & $11.13 \pm 1.03$ & $11.88 \pm 1.31$ & $12.88 \pm 1.55$ & $10.68 \pm 0.90$ & $\mathrm{~ns}$ \\
Left Epididymal Weight $(\mathrm{g})$ & $5.00 \pm 0.32$ & $5.52 \pm 0.39$ & $5.18 \pm 0.52$ & $5.68 \pm 0.43$ & $\mathrm{~ns}$ \\
Right Epididymal Weight $(\mathrm{g})$ & $5.50 \pm 0.53$ & $5.15 \pm 0.43$ & $4.52 \pm 0.49$ & $4.95 \pm 0.46$ & $\mathrm{~ns}$ \\
Paired Epididymal Weights $(\mathrm{g})$ & $5.25 \pm 0.27$ & $5.33 \pm 0.36$ & $4.85 \pm 0.37$ & $5.32 \pm 0.31$ & $\mathrm{~ns}$ \\
Left Ductus Deferens $(\mathrm{g})$ & $0.72 \pm 0.09$ & $0.78 \pm 0.11$ & $0.83 \pm 0.10$ & $0.62 \pm 0.13$ & $\mathrm{~ns}$ \\
Right Ductus Deferens $(\mathrm{g})$ & $0.83 \pm 0.05$ & $0.90 \pm 0.13$ & $0.88 \pm 0.11$ & $0.63 \pm 0.12$ & $\mathrm{~ns}$ \\
Paired Ductus Deferens $(\mathrm{g})$ & $0.78 \pm 0.06$ & $0.84 \pm 0.11$ & $0.86 \pm 0.09$ & $0.63 \pm 0.13$ & $\mathrm{~ns}$ \\
\hline
\end{tabular}

LS, level of significance; ns= not significant, SEM, Standard error of the means.

weights of cockerels in the different dietary groups. Although, cockerels on diets containing CPM had numerically higher gizzard weight than those on control diet, there was no pattern of change in gizzard weight with increasing levels of CPM in the diets. Thus, these suggest that inclusion of sun-dried cassava peels up to a level of $30 \%$ in the diets of cockerels did not have any deleterious effect on cockerel production. Pido et al. (1979) in a related study, supplemented maize with a maximum of $50 \%$ Fermented Cassava Meal (FCM) and 
Table 3. Effect of Cassava Peel Meal on Visceral Organ Weights of Cockerels (Mean \pm SEM).

\begin{tabular}{lccccc}
\hline \multirow{2}{*}{ Parameter } & \multicolumn{3}{c}{ Diets } & LS \\
\cline { 2 - 5 } & $\mathbf{1 ( 0 \% )}$ & $\mathbf{2 ( 1 0 \% )}$ & $\mathbf{3 ( 2 0 \% )}$ & $\mathbf{4 ( 3 0 \% )}$ & \\
\hline Heart $(\mathrm{g})$ & $11.80 \pm 0.45$ & $10.62 \pm 0.46$ & $12.04 \pm 1.05$ & $10.00 \pm 0.55$ & $\mathrm{~ns}$ \\
Heart (\%) & $0.45 \pm 0.02$ & $0.44 \pm 0.03$ & $0.47 \pm 0.03$ & $0.41 \pm 0.02$ & $\mathrm{~ns}$ \\
Gizzard (g) & $52.50 \pm 2.17$ & $57.92 \pm 5.92$ & $54.90 \pm 2.69$ & $57.43 \pm 2.98$ & $\mathrm{~ns}$ \\
Gizzard (\%) & $2.01 \pm 0.07$ & $2.36 \pm 0.20$ & $2.21 \pm 0.15$ & $2.35 \pm 0.14$ & $\mathrm{~ns}$ \\
Abdominal Fat (g) & $0.77 \pm 0.12$ & $0.67 \pm 0.17$ & $0.65 \pm 0.12$ & $0.82 \pm 0.19$ & $\mathrm{~ns}$ \\
Abdominal Fat (\%) & $0.029 \pm 0.005$ & $0.028 \pm 0.008$ & $0.026 \pm 0.005$ & $0.034 \pm 0.009$ & $\mathrm{~ns}$ \\
Spleen (g) & $3.05 \pm 0.25$ & $3.30 \pm 0.59$ & $2.83 \pm 0.29$ & $3.10 \pm 0.38$ & $\mathrm{~ns}$ \\
Spleen(\%) & $0.117 \pm 0.010$ & $0.138 \pm 0.029$ & $0.113 \pm 0.011$ & $0.10 \pm 0.015$ & $\mathrm{~ns}$ \\
Liver (g) & $26.95 \pm 1.72$ & $26.40 \pm 0.58$ & $24.60 \pm 1.49$ & $25.92 \pm 1.05$ & $\mathrm{~ns}$ \\
Liver (\%) $(1.037 \pm 0.079$ & $1.087 \pm 0.050$ & $0.980 \pm 0.037$ & $1.04 \pm 0.39$ & $\mathrm{~ns}$ \\
Lungs (g) & $7.58 \pm 0.35$ & $7.64 \pm 0.54$ & $7.03 \pm 0.40$ & $6.49 \pm 0.46$ & $\mathrm{~ns}$ \\
Lungs (\%) & $0.290 \pm 0.016$ & $0.313 \pm 0.020$ & $0.282 \pm 0.016$ & $0.25 \pm 0.18$ & $\mathrm{~ns}$ \\
Kidneys $(\mathrm{g})$ & $3.97 \pm 0.22$ & $3.93 \pm 0.24$ & $5.27 \pm 1.19$ & $3.82 \pm 0.26$ & $\mathrm{~ns}$ \\
Kidneys $(\%)$ & $0.153 \pm 0.010$ & $0.160 \pm 0.010$ & $0.211 \pm 0.048$ & $0.155 \pm 0.008$ & $\mathrm{~ns}$ \\
\hline
\end{tabular}

LS, level of significance; ns= not significant, SEM, Standard error of the means.

obtained comparable heart weight values.

Bitto et al. (1999) fed graded levels of CPM to 10 weeks old cockerels and obtained similar testis, epididymal and ductus deferens weights. The nonsignificant effect of dietary inclusion of CPM on paired ductus deferens weights suggests stability on sperm storage and rate of passage in birds raised on CPM. Udedibie et al. (1988) obtained higher visceral weights in broilers confirming the influence of feed ingredients, class of poultry, age and breed on visceral organ weights. Results of abdominal fat weight recorded in this study agree with the observations of Le Clercq (1985) who reported that male birds are homozygous for leanness, have abdominal fat making up about $0.7 \%$ of body weight. Cockerel ration increases in energy from 13 weeks and this result in declining abdominal fat. Sonaiya (1986) observed that abdominal fat variables steadily increased from the 8th to the 13th week (1.16\%), declines up to the 15 th week $(0.73 \%)$, before increasing again at the 16th week. Rather than fat deposition, the energy demand is apparently required for non-carcass use such as the development of sexual organs and sexual activity. The record of enlarged testes weight supports the above claim. Panigrahi et al. (1992) obtained slightly lower liver values with the incorporation of $250 \mathrm{~g} / \mathrm{kg}$ fast dried, $500 \mathrm{~g} / \mathrm{kg}$ fast dried, $250 \mathrm{~g} / \mathrm{kg}$ slowly dried and $500 \mathrm{~g} / \mathrm{kg}$ slow dried cassava root into broiler starter ration. The average liver weights in birds fed the controlled diets was generally higher than the weight of birds fed the treated diets, which means that CPM did not enlarge the liver weights. Atuahuene et al. (1986) obtained slightly lower liver weight values with a maximum of $10.0 \%$ cottonseed meal inclusion in broiler starter rations. Pido et al. (1979) replaced maize with a maximum of $50.0 \%$ Fermented Cassava Meal (FCM) and obtained $2.20 \%$ liver weights. Udedibie (1988) also obtained $1.90 \%$ liver weight values with $20.0 \%$ replacement of protein with Poultry Offal Meal (POM) in broiler finisher rations. Different liver values obtained in the above researches could be because of age, breed, and class of poultry, methods of drying and nutritional composition of the various diets.

\section{CONCLUSION}

The inclusion of sun-dried cassava peel meal up to a level of $30 \%$ has no adverse effect on the morphometric characteristics of the reproductive organs as well as the visceral organ weights of cockerels.

\section{CONFLICT OF INTEREST}

The author declares that there is no conflict of interest.

\section{REFERENCES}

Abu, O. A., Olaleru, I. F., Oke, T. D., Adepegba, V. A., \& Usman, B. (2015). Performance of broiler chickens fed diets containing cassava peel and leaf meals as replacements for maize and Soya bean meal. Int. J. Sci. Technol., 4(4), 169173.

Adeyemo, I. A., Sani, A., \& Aderibigbe, T. A. (2013). Growth performance and nutrient retention of broiler chickens fed Aspergillus niger hydrolysed cassava peel based diet. American Journal of Research Communication, 7, 294-306.

Ahmed, I. G. (2004). An overview of the Nigerian Pan- African Programme for the control of Epizootics (PACE)- Information paper presented at the Training Workshop for Private Veterinarians held at NTI Conference Centre, Kaduna, February 17-19, 2004, Pp. 2-12. 
Aina, A. B. J. (1990). Replacing maize with cassava peels in finishing ration for cockerels. Nigerian Journal of Animal Production, 17, 17-22.

Atuahuene, C. C., Donkoh, A., \& Nkasah-Darko, P. (1986). Effects of raw cotton seed meal on the performance, carcass characteristics and certain blood parameters of broiler chickens. Journal of Animal Production Research, 6(2), 107114.

Bitto, I. I., Sende, C. T., \& Eze, P. U. (1999). Preliminary Investigation on the effect of cassava peel meal on testicular morphometric and some biochemical characteristics of serum in cockerels. Global Journal of Pure and Applied Sciences, 6(2), 161-165.

Cantner, E. W. (1987). Utilization of agricultural waste products in animal nutrition. Animal Research and Development, 26, 56-70.

Dairo, F. A. S., \& Egbeyemi, O. B. (2012). Response of weaner rabbits to diets containing fermented mixtures of cassava peel and dried caged layers manure. African Journal of Agricultural Research, 7(49), 6588-6594.

Gill, C. (2003). Feed ingredients versus pollution. Feed International, 24(12), 4.

Le Clercq, B. (1985). The genetic and physiological basis of fatness in poultry. Invited paper, Seventh European Symposium of poultry Meat Quality, Vjle, Denmark, 6-10 May. Pp.1-15.

Midau, A., Augustine, C., Yakubu, B., Yahaya, S. M., Kibon, A., \& Udoyong, A. O. (2011). Performance of broiler chicken fed enzyme supplemented cassava peel meal based diets. Int $J$ Agr. Sustain, 3, 1-4.

Ogbonna, J. U. (1991). Studies on the value of processed cassava peels in nutrition of cockerels, $\mathrm{PhD}$ Thesis University of Ibadan, Ibadan, Nigeria. Pp. 1-50.

Ogbonna, J. U., \& Adebowale, E. A. (1993). The effects of sundried cassava peel meal as replacement of maize and what offals on performance and nutrient utilization of cockerels. Nigerian Journal of Animal Production, 20, 61-70.
Oladunjoye, I. O., Oojebiyi, O. O. and Rafiu, T. A. (2014) High methionine supplementation improves the nutritional value of cassava peel meal for broiler chicken. Livestock Research for Rural Development, 26(4). www.Irrd.org/lrrd26/4/ olad26063.htm . Article \#63, Retrieved Mat 14, 2017.

Osei, S. A., \& Duodu, S. (1988). The use of sun-dried cassava peel meal in broiler diet. Journal of Animal Research, 8(2), 69-75.

Panigrahi, S., Richard, J., O’Brien, G. M., \& Gay, C., (1992). The effects of different rate of drying cassava roots on its toxicity to broiler chicks. British Poultry Science, 33, 10251042.

Parr, W. H., Capper, B. S., Cox, D. R. S., Jewers, K., Marter, A. D., Nicholas, W. , Silvey, D. R., \& Wood, J. F. (1988). The small-scale manufacture of compound animal feed. ODNRI Bulletin, 19, 1-17.

Pido, P. P., Adeyanju, S. A., \& Adegbola, A. A. (1979). The effect of graded levels of fermented cassava meal on broilers. Poultry Science, 58(2), 427-431.

Sonaiya, E. B. (1986). Live and carcass performance of cockerels raised to 16 weeks on two calorie protein rations. Animal Production Research, 6(1), 73-76.

Steel, R. G., \& Torrie, J. H. (1980). Principles and Procedures of Statistics. McGraw-Hill Book Company, New York.

Udedibie, A. B. I., Anyanwu, G. \& Oyet, A. J. (1988). Poultry offal meal as a protein supplement of laying hens and finisher broilers. Nigerian Journal of Animal Production, 15, 103-109. 